\title{
Effect of Various Curing Methods and Curing Ages on Compressive Strength of Plain Concrete
}

\author{
Muhammad Saleem Raza ${ }^{1,}$, Haresh Kumar ${ }^{2}$, Kunal Rai $^{3}$, Danish Kumar ${ }^{4}$, Naraindas Bheel ${ }^{5}$ \\ ${ }^{1}$ Department of Civil Engineering, MUET, Jamshoro, Pakistan. \\ ${ }^{2}$ Institute of Environmental Engineering and Management (IEEM), MUET, Jamshoro, Pakistan. \\ ${ }^{3}$ Department of Civil, Chemical, Environmental and Materials Engineering (DICAM), University of Bologna, Italy. \\ ${ }^{4}$ Ministry of Planning, Development and Special Initiatives of Federal Government of Pakistan. \\ ${ }^{5}$ Department of Civil and Environmental Engineering, Universiti Teknologi PETRONAS, Malaysia. \\ ${ }^{*}$ Corresponding author: saleemraza43@yahoo.com
}

\section{Abstract}

Concrete is the most important and most consumed construction material in global construction industry. The properties of concrete are greatly influenced by properties of its constituents and curing methods utilized for preparation of specimens. This study is focused on investigating the influence of three common curing methods, i.e., ponding, sprinkling and wet cover curing on compressive strength behavior of concrete. In total, 45 cubes were casted and tested after curing for 3, 7, 14, 28 and 56 days. The obtained results suggest that ponding method of concrete curing is most effective among all the three methods of concrete curing considered in this study. After ponding, the performance of concrete cured with wet cover curing method was quite acceptable. Moreover, the study also suggested that sprinkling method of curing gives lowest compressive strength due to greater moisture movement which abates the hydration of binder in concrete. This study will be helpful for construction practitioners in deciding the best-suited curing method under given conditions and available methods of preparation of concrete.

Keywords-Concrete, Curing, Curing Methods, Compressive Strength

\section{Introduction}

$\mathrm{C}$ ONCRETE is being widely adopted as construction material since ages because of its availability, versatility and durability [1]. It is a man-made construction material composed of cement, fine aggregates, coarse aggregates and water [2][3]. The cement in concrete acts as a binder that sets and hardens other components of concrete together while the aggregates are employed for adequate bonding [2]. This process of setting and hardening of cement is a chemical process called as hydration which is caused and accelerated by water used for curing of concrete [4]. As the hydration of cement is an exothermic chemical reaction that emits considerable amount of heat, the curing temperature below $10^{\circ} \mathrm{C}$ i.e. $50^{\circ} \mathrm{F}$ is not acceptable [5]. The improper curing of concrete can result in loss of half of its strength and proper

ISSN: 2523-0379 (Online), ISSN: 1605-8607 (Print)

DOI: 10.52584/QRJ.1802.04

This is an open access article published by Quaid-e-Awam University of Engineering Science \& Technology, Nawabshah, Pakistan under CC BY 4.0 International License. curing of concrete ensures $90 \%$ attainment of concrete strength [6]. For proper curing, adequate moisture and temperature should be provided to concrete [5]. Hence, the curing of concrete is of extreme importance as it ensures the attainment of design strength and decreases the occurrence of surface cracks [4].

Curing not only reduces the shrinkage and permeability loss, but it also protects it from strength and durability losses, essentially on early days of strength gain [5]. The prime purpose of concrete curing in early age is to provide concrete enough amount of water for strength gains [6]. Based on conditions and availability, various methods for concrete curing are employed such as curing with gunny bags, curing with potable water, air curing, polythene curing, steam curing, ponding, sprinkling, wet covering etc. [5][7][8].

The curing of concrete with potable water involves sprinkling and/or ponding methods. In sprinkling method, the concrete is sprayed by water and in ponding method, concrete specimens are kept 
immersed in water for certain curing regimes [5]. The gunny bags curing and/or polythene sheet curing fall under the category of curing with wet covering. The concrete samples are kept under gunny bags, polythene sheets and/or wet burlaps for providing moisture to concrete matrix for hydration process [9]. Similarly, in air curing, the concrete units are placed in stacks at room temperature to allow free flow of ambient air for curing [8]. The claim has been made [8] that the concrete cured by air exhibits 10\%-20\% lesser strength than the concrete cured by water. The behavior of concrete incorporating recycled aggregates at replacement levels of $0 \%, 25 \%$, $50 \%$ and $100 \%$ under different curing methods i.e. air curing, water curing and painted curing was studied [10]. The study concluded that curing with paint materials was beneficial for strength gain except in case of $100 \%$ replacement of aggregates. Moreover, the concrete cured by water showed greater strength than the concrete cured by air [10]. Similar results were obtained as the authors in [11] concluded that concrete cured by ponding (immersing in the water) showed greater compressive, tensile and flexural strength than the concrete cured by air and wet plastic film. For hot weather conditions, the wet burlap sheet covering method was suggested [12]. This study also urged that a mini-mum of 3 days wet burlap curing should be ensured for rich concrete mixes and similarly, 7 days wet burlap curing for lean concrete mixes should be ensured [12]. It is very much necessary that the minimum curing period should be optimized in relation to the required proper-ties of concrete as the concrete mixtures prepared with pozzolanic admixtures are more sensitive than the plain concrete [13]. It is a well-established fact that curing of concrete provides strength to concrete matrix. Moreover, the curing days also influence the strength development process in concrete units.

This study, therefore, aims at checking the influence of various curing methods and curing days on compressive strength of plain cement concrete. The study compared the influence of ponding, spraying and wet cover curing on compressive strength of un-reinforced concrete. The curing regimes were selected as $3,7,14,28$ and 56 days.

\section{Materials and Methods}

The materials utilized in this study are basic components of plain cement concrete, i.e., aggregates, cement and water. The potable water with $\mathrm{pH}$ value of 7.4 , complying to requirements prescribed in [14]

\begin{tabular}{|c|c|c|c|}
\hline Oxide & Percentage & Oxide & Percentage \\
\hline $\mathrm{SiO}_{2}$ & $20.67 \%$ & $\mathrm{Fe}_{2} \mathrm{O}_{3}$ & $3.2 \%$ \\
\hline $\mathrm{CaO}$ & $59.63 \%$ & $\mathrm{SO}_{3}$ & $2.49 \%$ \\
\hline $\mathrm{MgO}$ & $3.66 \%$ & $\mathrm{~K}_{2} \mathrm{O}$ & $0.67 \%$ \\
\hline $\mathrm{Na}_{2} \mathrm{O}$ & $0.12 \%$ & $\mathrm{LOI}$ & $8.44 \%$ \\
\hline $\mathrm{Al}_{2} \mathrm{O}_{3}$ & $6.03 \%$ & - & - \\
\hline
\end{tabular}

TABLE 1: Chemical composition of ordinary portland cement

\begin{tabular}{|c|c|c|c|c|c|}
\hline $\begin{array}{c}\text { Curing } \\
\text { Methods }\end{array}$ & \multicolumn{5}{|c|}{ Number of Cubes } \\
\cline { 2 - 6 } & $\begin{array}{c}\mathbf{3} \\
\text { Days }\end{array}$ & $\begin{array}{c}\mathbf{7} \\
\text { Days }\end{array}$ & $\begin{array}{c}\mathbf{1 4} \\
\text { Days }\end{array}$ & $\begin{array}{c}\mathbf{2 8} \\
\text { Days }\end{array}$ & $\begin{array}{c}\mathbf{5 6} \\
\text { Days }\end{array}$ \\
\hline Ponding & 3 & 3 & 3 & 3 & 3 \\
\hline Sprinkling & 3 & 3 & 3 & 3 & 3 \\
\hline $\begin{array}{c}\text { Wet Cover } \\
\text { Curing }\end{array}$ & 3 & 3 & 3 & 3 & 3 \\
\hline Total Cubes & \multicolumn{5}{|c|}{$3 \times 3 \times 5=45$} \\
\hline
\end{tabular}

TABLE 2: Details of concrete cubes prepared for compressive strength test

was utilized for preparation of concrete. The Ordinary Portland cement (OPC) of Grade 43 conforming to prescriptions set in [15] was used for conduct of this research. The chemical composition of OPC is detailed in Table 1. The initial and final setting time of cement was 50 minutes and 214 minutes respectively. The fine and coarse aggregates conforming to guidelines of [16] were utilized. The water absorption and specific gravity of fine aggregates was $1.25 \%$ and 2.5. Similarly, the water absorption and specific gravity of coarse aggregates was $2.67 \%$ and 2.71 .

The concrete mix ratio was maintained as 1:1.5:3 and the targeted strength was $25 \mathrm{MPa}$. For preparation of concrete specimens prepared for compressive strength test, the standards of [17] were strictly followed. In total, 45 number of cubes of size $150 \times 150 \times 150 \mathrm{~mm}$ were casted for compressive strength testing as detailed in Table 2. The universal testing machine (UTM) was used for compressive strength testing of cubes at the end of the respective curing age in accordance with guidelines of [18]. For curing of concrete specimens, three methods i.e. ponding, sprinkling and wet cover curing were considered, and the results were compared. For curing of concrete specimens via ponding method, the concrete cubes were immersed completely in the water for respective curing ages. Throughout this process, the average laboratory temperature equivalent to standard room temperature was maintained in order to avert the possible thermal stresses that could further lead towards development of cracks. As ponding ensures continuous supply of moisture and uniform temperature, it is considered to be an ideal method for curing. For curing via sprinkling method, the concrete 


\begin{tabular}{|c|c|c|c|c|}
\hline \multirow{2}{*}{$\begin{array}{c}\text { Curing } \\
\text { Method }\end{array}$} & \multicolumn{2}{|c|}{$\begin{array}{c}\text { Compressive } \\
\text { Strength (MPa) }\end{array}$} & \multicolumn{2}{c|}{$\begin{array}{c}\text { Percentage } \\
\text { Difference }\end{array}$} \\
\cline { 2 - 5 } & 7 Days & 28 Days & 7 Days & 28 Days \\
\hline Ponding & 16.83 & 25.93 & - & - \\
\hline Sprinkling & 15.32 & 25.52 & $-8.97 \%$ & $-1.58 \%$ \\
\hline $\begin{array}{c}\text { Wet Cover } \\
\text { Curing }\end{array}$ & 16.62 & 25.83 & $-1.25 \%$ & $-0.39 \%$ \\
\hline
\end{tabular}

TABLE 3: Percentage difference of compressive strength values at $7 \& 28$ days of curing

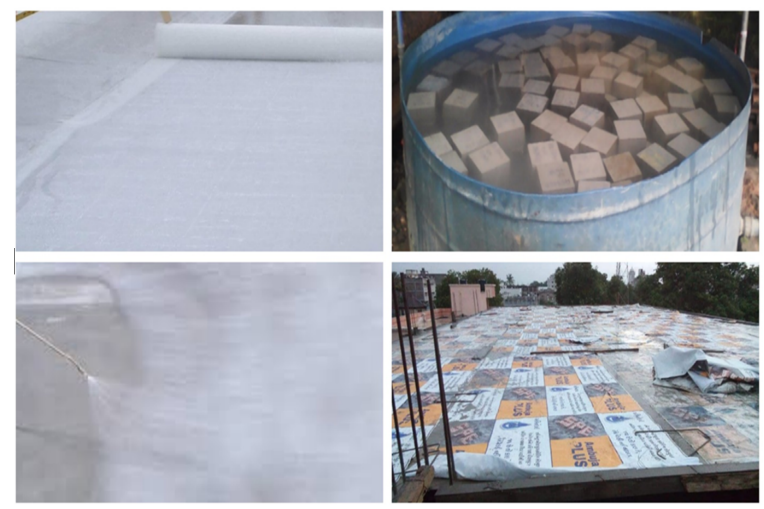

Fig. 1: Demonstration of various curing methods involved.

specimens were periodically showered with potable water available in the laboratory. However, as sprinkling re-quires supply of ample amount of water and careful supervision, the cost and human resource involved in it can be a major point of concern. In addition, the wet cover curing method employed the wet sheets in order to maintain the presence of water on the outer surface of complete area of concrete cubes. The wet coverings were provided to the cubes soon after the acquirement of enough strength by concrete cubes in order to prevent the possible surface damage, especially on edges. Figure 1 shows these three methods of concrete curing, adopted in this study.

\section{Results \& Discussion}

This study involved checking the influence of three common curing methods i.e. ponding, sprinkling and wet cover curing on compressive strength behavior of concrete cubes. The cubes were subjected to curing for $3,7,14,28$ and 56 days. The concrete cubes were tested for compressive strength and it was observed that the ponding method of curing provided more strength than the wet cover curing method of curing followed by sprinkling method. The results are detailed in Table 3 in terms of percentage difference of compressive strength values obtained at testing after 7 and 28 days of curing of concrete cubes.

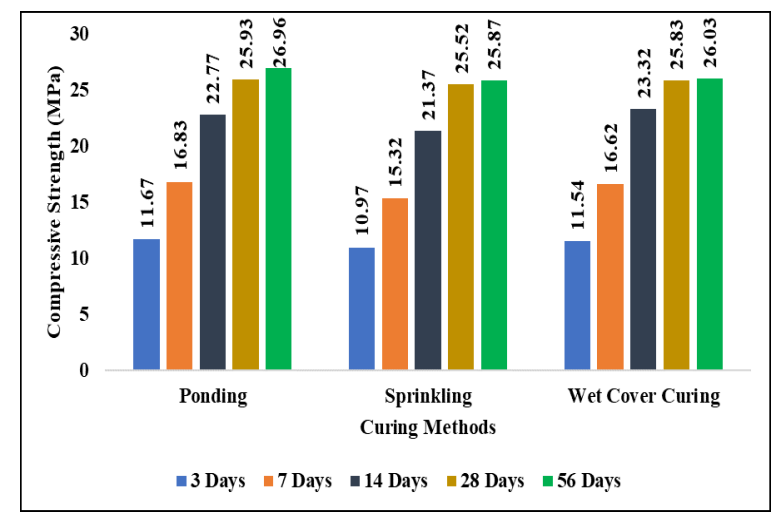

Fig. 2: Relation between curing methods, curing ages and compressive strength of concrete cubes.

It was also observed that role of curing regimes was very crucial and important for strength development in concrete cubes. The curing of concrete by ponding helps in balancing the heat of hydration and aids in adequate strength development phenomenon. The heat of hydration is basically balanced and maintained through low porosity behavior caused by hear of hydration which results in loss of moisture. Moreover, the strength loss in sprinkling method is because of increased moisture movement from concrete which results in early drying of the concrete, ultimately abating the entire hydration process. The concrete cured by ponding method was helpful in achieving the design strength of structural concrete i.e. $25 \mathrm{MPa}$. These results are in agreement with those obtained in [4] and [5]. The results are graphically illustrated as under in Figure 2.

\section{Conclusions \& Future Recommendations}

The present study investigated the effect of various curing methods i.e. ponding, sprinkling and wet cover curing and curing days i.e. $3,7,14,28$ and 56 days on compressive strength of concrete cubes.

- The results depicted that sprinkling provides lowest of compressive strengths ob-served in this study

- Although, the ponding method of concrete curing provided greater strength than that provided by sprinkling method, the performance of concrete cured with both methods was quite comparable.

- Considering the results, this study recommends ponding method for curing of concrete.

Moreover, the effects of other methods say as air curing, solar curing, wet hessian curing and polythene sheet curing, steam curing etc. on strength behavior of concrete should also be studied in detail. In addition, 
other properties such as tensile and flexural strength values, fire and abrasion resistance, cracking behavior, permeability and durability of concrete can be checked for concrete subjected to different curing methods and curing days.

\section{References}

[1] M. A. Jatoi, G. S. Solangi, F. A. Shaikh, S. Khan, and S. Ahmed, "Effect of Lakhra Fly Ash as Partial Replacement of Cement in Traditional Concrete," Mehran Univ. Res. J. Eng. Technol., vol. 38, no. 4, pp. 1045-1056, 2019.

[2] M. S. Raza, K. Rai, D. Kumar, and M. Ali, "Experimental Study of Physical, Fresh-State and Strength Parameters of Concrete incorporating Wood Waste Ash as a Cementitious Material," J. Mater. Eng. Struct., vol. 7, no. 2, pp. 267-276, 2020.

[3] S. A. Mangi, A. Makhija, M. S. Raza, S. H. Khahro and A. A. Jhatial, "A Comprehensive Review on Effects of Seawater on Engineering Properties of Concrete," Silicon, 2020.

[4] A. Raza, B. A. Memon, and M. Oad, "Effect of Curing Types on Compressive Strength of Recycled Aggregates Concrete," QUEST Res. J., vol. 17, no. 2, pp. 7-12, 2019.

[5] T. James, A. Malachi, E. W. Gadzama, and V. Anametemfiok, "Effect of Curing methods on compressive strength of concrete," Niger. J. Technol., vol. 30, no. 3, pp. 14-20, 2011.

[6] R. P. Memon, A. R. M. Sam, A. Z. Awang, and U. I. Memon, "Effect of Improper Curing on the Properties of Normal Strength Concrete," Eng. Technol. Appl. Sci. Res., vol. 8, no. 6, pp. 3536-3540, 2018.

[7] A. A. Raheem, A. A. Soyingbe, and A. J. Emenike, "Effect of Curing Methods on Density and Compressive Strength of Concrete," Int. J. Appl. Sci. Technol., vol. 3, no. 4, pp. 55-64, 2013.

[8] D. M. Boakye, H. C. Uzoegbo, N. Mojagotlhe, and M. Malemona, "Effect of different curing methods on the compressive strength development of pulverized copper slag concrete," J. Mater. Eng. Struct., vol. 1, no. 1, pp. 11-21, 2014.

[9] A. M. Zeyad, "Effect of curing methods in hot weather on the properties of high-strength concretes," J. King Saud Univ. - Eng. Sci., vol. 31, no. 3, pp. 218-223, 2019.

[10] A. S. Abdel-Hay, "Properties of recycled concrete aggregate under different curing conditions," HBRC J., vol. 13, no. 3, pp. 271-276, 2017.

[11] A. Goel, J. Narwal, V. Verma, D. Sharma, and B. Singh, "A Comparative Study on the Effect of Curing on the Strength of Concrete," Int. J. Eng. Adv. Technol., vol. 2, no. 6, pp. 401-406, 2013.

[12] S. H. Al-Ani and M. A. K. Al-Zaiwary, "The effect of curing period and curing delay on concrete in hot weather," Mater. Struct., vol. 21, no. 123, pp. 205-212, 1988.

[13] M. S. Khan and M. E. Ayers, "Minimum Length of Curing of Silica Fume Concrete," J. Mater. Civ. Eng., vol. 7, no. 2, pp. 134-139, 1995.

[14] "ASTM C1602 / C1602M - 18 Standard Specification for Mixing Water Used in the Production of Hydraulic Cement Concrete." .

[15] "ASTM C150 / C150M-19a, Standard Specification for Portland Cement, ASTM International, West Conshohocken, PA." pp. 1-10, 2019.

[16] ASTM C33 / C33M-18, Standard Specification for Concrete Aggregates. 2018.
[17] "ASTM C192 / C192M - 19 Standard Practice for Making and Curing Concrete Test Specimens in the Laboratory." .

[18] "BS EN 12390-3:2019 - Testing hardened concrete. Compressive strength of test specimens.". 